\title{
Turnover of Mammalian Phospholipids
}

\author{
RATES OF TURNOVER AND METABOLIC HETEROGENEITY IN CULTURED HUMAN \\ LYMPHOCYTES AND IN TISSUES OF HEALTHY, STARVED AND VITAMIN A-DEFICIENT \\ RATS
}

\author{
By C. A. PASTERNAK AND BEVERLY FRIEDRICHS \\ Department of Biochemistry, University of Oxford, Oxford OXI 3QU, U.K.
}

(Received 11 May 1970)

\begin{abstract}
1. Choline- and inositol-labelled phospholipids of human cultured lymphocytes turn over in a biphasic manner; phytohaemagglutinin activation stimulates turnover. 2. Choline-labelled phospholipids of rat liver and kidney, but not of blood, turn over in vivo as fast as those of duodenum, ileum or colon. Turnover in the intestinal tissues is greater in fed than in starved or vitamin A-deficient rats. In each case phosphatidylcholine turns over relatively faster than sphingomyelin or lysophosphatidylcholine. 3. It is concluded that phospholipid turnover of the type described is a common feature of viable cells, and that metabolically favourable conditions increase, rather than decrease, turnover.
\end{abstract}

Experiments with neoplastic mast cells have shown that phospholipids turn over during exponential growth under conditions in which total protein and other macromolecules are stable (Pasternak, 1969; Pasternak \& Bergeron, 1970). Since it was suggested by Warren (1969) that turnover of animal membranes, of which phospholipids are a key component (Van Deenen, 1966; Stoeckenius \& Engelman, 1969), may be increased in cancer cells, the behaviour of normal lymphocytes under growing (phytohaemagglutininstimulated; Nowell, 1960), and non-growing conditions has been examined. Phospholipid turnover in whole animals is well documented (Dawson, 1957, 1966), but little is known of its relation to turnover in cultured cells (Pasternak \& Bergeron, 1970) or of its metabolic significance. The effect of nutritional variation (e.g. Artom, Sarzana \& Segré, 1938; Bailey, Taylor \& Bartley, 1967) might yield information on these points, and since it has been suggested (Dingle \& Lucy, 1965) that the integrity and function of animal membranes depends on the presence of vitamin $A$, it was decided to study the turnover of phospholipid in healthy, starved and vitamin A-deficient animals.

Turnover of choline-containing and inositolcontaining phospholipids of neoplastic mast cells follows a biphasic pattern, indicative of metabolically stable and unstable components. With choline, the unstable component is largely phosphatidylcholine, whereas the stable component is relatively richer in sphingomyelin (Pasternak, 1969; Pasternak \& Bergeron, 1970). Although metabolic heterogeneity of animal phospholipids with respect to fatty acids has been observed by several groups (Collins, 1960; Harris, Robinson \& Getz, 1960; Isozaki, Yamamoto, Amako, Sakai \& Okita, 1962; Balint, Beeler, Treble \& Spitzer, 1967; Arvidson, 1968; Rytter, Miller \& Cornatzer, 1968; Kanoh, 1969 ; Spitzer, Norman \& Morrison, 1969 ; Van Golde, Scherphof \& Van Deenen, 1969), less is known of the relative turnover of different phospholipids (Gross, Getz \& Rabinowitz, 1969; Smith, 1969). It therefore seemed worthwhile to investigate to what extent the pattern of turnover of choline-labelled phospholipids seen in neoplastic mast cells is typical of other tissues.

\section{EXPERIMENTAL}

Rat tissues. Male Wistar rats either were fed on Oxoid Pasteurized Breeding diet ad libitum ('healthy rats') or were pair-fed on the diet with or without vitamin A acid described by Thomas \& Pasternak (1969) ('starved rats'). 'Control' and vitamin A-deficient rats of equal weights were used when approx. 3 weeks old, by which time all deficient rats were losing weight. In one experiment, male and female rats, kindly given by the Nuffield Laboratory of Ophthalmology, were fed on a diet containing casein, vitamin-free and fat-free (BDH Chemicals Ltd., Poole, Dorset, U.K.) (150 g), rice starch (BDH Chemicals Ltd.) $(600 \mathrm{~g})$, mineral salts (BDH Chemicals Ltd.) (40g), brewer's yeast (Boots Pure Drug Co., Nottingham, U.K.) $(60 \mathrm{~g})$ and arachis oil B.P. (Evans Medical Ltd., Speke, Lancs., U.K.) (150 ml). Vitamin D (40 i.u.) and vitamin A (Prepalin; 400 i.u.) were administered twice weekly by mouth; in this instance, pair feeding was not carried out,

Bioch. 1970, 119 
so that control (healthy) rats weighed 170-260g and vitamin A-deficient rats (characterized by weight loss and eye symptoms) $120-180 \mathrm{~g}$, when used. Rats were lightly anaesthetized with ether and injected intraperitoneally with $\left[M e-{ }^{3} \mathrm{H}\right]$ choline $(13-400 \mu \mathrm{Ci} / \mathrm{g}$ body wt. $),\left[M e-{ }^{14} \mathrm{C}\right]$ choline $\left(10-25 \mu \mathrm{Ci} / \mathrm{g}\right.$ body wt.), $\left[1,2-{ }^{14} \mathrm{C}_{2}\right]$ choline $(1.3 \mu \mathrm{Ci} / \mathrm{g}$ body wt.), $\left[M e{ }^{3} \mathrm{H}\right]$ thymidine (TRA $120,5 \mathrm{Ci} / \mathrm{mmol}$; The Radiochemical Centre, Amersham, Bucks., U.K.) (100-250 $\mu \mathrm{Ci} / \mathrm{g}$ body wt.), $\left[2-{ }^{14} \mathrm{C}\right]$ thymidine $(10 \mu \mathrm{Ci} / \mathrm{g}$ body wt.) or $\left.{ }^{33} \mathrm{P}\right]$ phosphate $(5 \mu \mathrm{Ci} / \mathrm{g}$ body wt.); the specific radioactivities and origins of the labelled compounds were as stated by Pasternak \& Bergeron (1970). Non-radioactive choline $(0.5 \mathrm{ml}$ of $63 \mathrm{~mm}$-choline $/ 100 \mathrm{~g}$ body wt.) or thymidine $(0.5 \mathrm{ml}$ of $5 \mathrm{~mm}$-thymidine $/ 100 \mathrm{~g}$ body wt.) was injected $4 \mathrm{~h}$ after injection of labelled compound. Rats were killed at various times, and tissues $(300-500 \mathrm{mg}$ wet wt.) and blood $(0.6 \mathrm{ml})$ extracted either with $5 \mathrm{ml}$ of $5 \%$ $(w / v)$ trichloroacetic acid tollowed by solubilization in $\mathrm{NaOH}$ as described by Thomas \& Pasternak (1969), or with $12 \mathrm{ml}$ of chloroform-methanol $(2: 1, v / v)$ followed by washing with $0.58 \% \mathrm{NaCl}$ as described by Folch, Lees \& Sloane-Stanley (1957).

Lymphocytes. A crude preparation of lymphocytes was obtained as follows. Venous blood $(20 \mathrm{ml})$ was withdrawn, mixed with $10 \mathrm{ml}$ of Dextraven (6\% dextran in $0.9 \%$ $\mathrm{NaCl}$; Fisons Pharmaceuticals, Loughborough, Leics., U.K.)-Fischer's medium (Grand Island Biological Co., Grand Island, N.Y., U.S.A.) ( $1: 1, v / v)$, and left for $1 \mathrm{~h}$ at $37^{\circ} \mathrm{C}$. The supernatant fluid (approx. $20 \mathrm{ml}$ ) was removed with a bulb pipette and diluted to $50 \mathrm{ml}$ with Fischer's medium. This suspension contained approx. $10^{6}$ white cells $/ \mathrm{ml}$ (estimated by dilution in Tuerk solution as described by Baker, Silverton \& Luckcock, 1957) of which more than $50 \%$ were small lymphocytes. Labelled compounds (as described in Pasternak \& Bergeron, 1970) and phytohaemagglutinin (Burroughs Wellcome and Co., London N.W.1, U.K.) (0.6 ml of a solution made by dissolving the contents of one vial of freeze-dried material in $5 \mathrm{ml}$ of Fischer's medium, added to $25 \mathrm{ml}$ of lymphocyte suspension) were added and samples were incubated in screwcapped tubes or flasks at $37^{\circ} \mathrm{C}$. At intervals $0.1 \mathrm{~m}-\mathrm{NaHCO}_{3}$ was added to maintain the $\mathrm{pH}$ at approx. 7. Samples were removed and filtered as described by Pasternak \& Bergeron (1970). Alternatively, samples were centrifuged, the supernatant was poured off and the pellet suspended in $1 \mathrm{ml}$ of $5 \%(w / v)$ trichloroacetic acid and filtered in the same way. Turnover of labelled cells was detected by addition of unlabelled choline or inositol (2-20 mM final concentration). Cell number was monitored by assaying diluted samples with a Coulter model A counter. A setting of $i=5, t=70$ gave cell counts in good agreement with direct assay on a haemocytometer. All operations were carried out aseptically. Phospholipids were extracted by the method of Folch et al. (1957).

Fractionation of phospholipids. The lower phase (Folch et al. 1957) obtained after extraction of cells or tissues was evaporated to dryness, dissolved in a minimum amount of chloroform and subjected to t.l.c. as described by Pasternak \& Bergeron (1970). In one instance, the lower phase of extracts of rat tissues labelled simultaneously with $\left[{ }^{3} \mathrm{H}\right]$ choline and $\left[1,2-{ }^{14} \mathrm{C}_{2}\right]$ choline was first subjected to chromatography on a column of silicic acid as described by Pasternak \& Bergeron (1970); no radioactivity was found in the neutral-lipid fraction.
Determination of radioactivity. The methods described by Pasternak \& Bergeron (1970) were used.

\section{RESULTS AND DISCUSSION}

\section{Lymphocytes}

Activation by phytohaemagglutinin. Uptake of $\left[{ }^{14} \mathrm{C}\right]$ thymidine was used as a criterion of lymphocyte activation (Mueller \& Le Mahieu, 1966), since it was difficult to measure cell number during the experiment owing to clumping caused by residual erythrocytes, as well as to attachment of stimulated lymphocytes to glass (Forsdyke, 1967, 1968). A

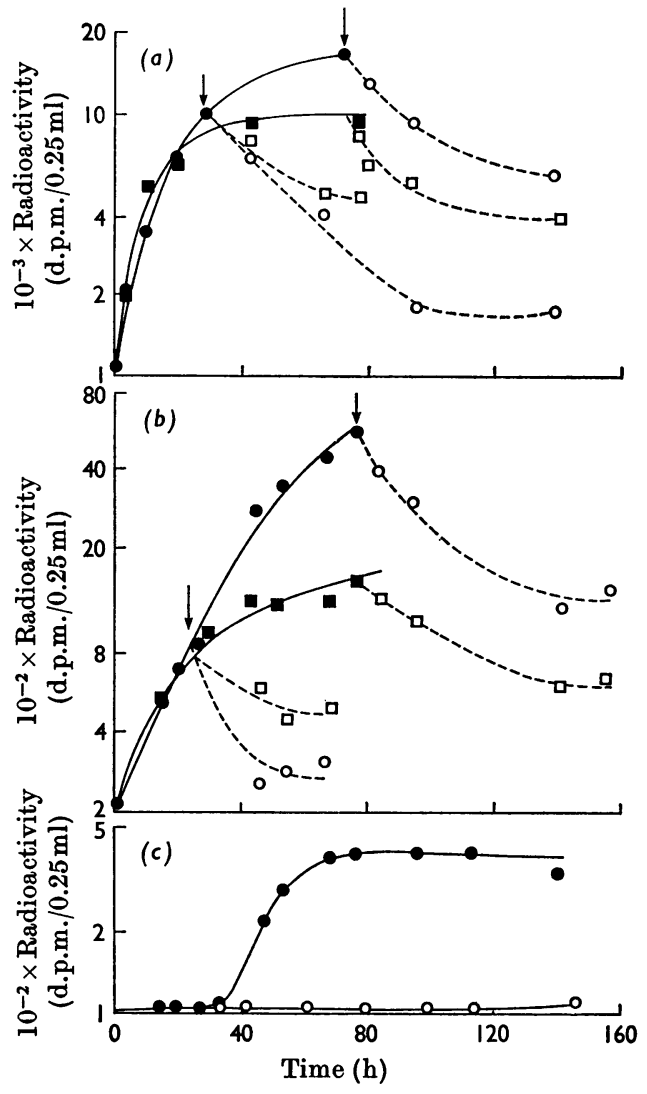

Fig. 1. Turnover of choline- and inositol-labelled phospholipid in cultured lymphocytes. Lymphocytes were incubated with phytohaemagglutinin (PHA) in the presence of $0.5 \mu \mathrm{Ci}$ of $\left[\mathrm{Me}^{3} \mathrm{H}\right] \mathrm{choline}$ or $\left[{ }^{3} \mathrm{H}\right] \mathrm{inositol} / \mathrm{ml}$ and $0.25 \mu \mathrm{Ci}$ of $\left[{ }^{14} \mathrm{C}\right]$ thymidine $/ \mathrm{ml}$, and duplicate samples $(0.25 \mathrm{ml})$ were assayed as described in the Experimental section. Unlabelled choline or inositol was added as indicated by the arrows. $(a)$ and $(b): a$, Uptake, and $\square$, turnover without PHA; $\bullet$, uptake and $\bigcirc$, turnover with PHA; (a) $\left[M e^{3} \mathrm{H}\right]$ choline; (b) $\left[{ }^{3} \mathrm{H}\right]$ inositol. (c) Uptake of $\left[{ }^{14} \mathrm{C}\right]$ thymidine, $O$, without and $\bullet$, with PHA. 
separate experiment in which cells were fractionated by the method of Roberts, Abelson, Cowie, Bolton \& Britten (1957) showed that incorporated ${ }^{14} \mathrm{C}$ was in the 'hot trichloroacetic acid' fraction. Stimulation of DNA synthesis occurred 2-3 days after addition of phytohaemagglutinin (Forsdyke, 1967, and Fig. 1).

Turnover of $\left[{ }^{3} \mathrm{H}\right]$ choline and $\left[{ }^{3} \mathrm{H}\right]$ inositol. Fig. 1 shows that when cells are incubated at $37^{\circ} \mathrm{C}$, $\left[{ }^{3} \mathrm{H}\right]$ choline and $\left[{ }^{3} \mathrm{H}\right]$ inositol are rapidly incorporated for the first $30-50 \mathrm{~h}$; the reason for the decrease in uptake at later times is not clear. Incorporation of label is into the lipid fraction of cells, that of choline being predominantly (mean, 87\%) into lecithin (Fisher \& Mueller, 1969). Unlike the situation in neoplastic mast cells (Pasternak \& Bergeron, 1970) or certain rat tissues in vivo (Table 3), there is rather little change, especially in the absence of phytohaemagglutinin, in the distribution of radioactivity between phosphatidylcholine, sphingomyelin and lysophosphatidylcholine during turnover. The uptake of inositol, and to a lesser extent of choline, is stimulated by phytohaemagglutinin (Fisher, 1968; Kay, 1968; Fisher \& Mueller, 1969). [ $\left.{ }^{3} \mathrm{H}\right]$ Choline- and $\left[{ }^{3} \mathrm{H}\right]$ inositol-labelled phospholipids turn over in a biphasic manner (Fig. 1), reminiscent of the behaviour of neoplastic mast cells (Pasternak \& Bergeron, 1970). Activation by phytohaemagglutinin causes an increased turnover of choline-labelled, and especially of inositol-labelled (Fisher, 1968), phospholipids (Fig. 1).

The fact that activation by phytohaemagglutinin increases, rather than decreases, the synthesis and degradation of phospholipids in lymphocytes, coupled with the fact that phospholipid turnover is greater in regenerating than in normal liver (Levin, Johnson \& Albert, 1958), lends support to the suggestion (Pasternak \& Bergeron, 1970) that phospholipid turnover may be an integral function of viable cells. It contrasts with the view (Warren, 1969) that turnover of membrane constituents is a feature of static as opposed to growing cells, and is faster in cancer cells than in normal cells; it also throws doubt on the suggestion (Warren, 1969) that increased turnover may lead to decreased adhesiveness to glass, since phytohaemagglutinin-stimulated cells adhere more strongly than do unstimulated ones (Forsdyke, 1967, 1968). Whether turnover in lymphocytes reflects some phagocytic (Elsbach, 1967) or repair (Warren, 1969) process, or is otherwise concerned with the synthesis (Fisher \& Mueller, 1969) or function (see below) of membranes, remains to be seen. What is clear is that the turnover described here is not concerned specifically with the process of mitosis, since it occurs in non-growing cells and because in dividing cells it takes place long before DNA replication (Kay, 1968; Fisher \& Mueller, 1969; Fig. 1). This situation is in contrast with that reported for bacteria (Daniels, 1969; Lubochinsky \& Burger, 1969), in which phospholipid synthesis occurs predominantly during cell division. Whether mitosis in animals is accompanied by more turnover, as is the case in regenerating liver (Levin et al. 1958), was not examined. Experiments with synchronized neoplastic mast cells confirm the present resultsin that synthesis and turnover of phospholipid is found to take place in the intermitotic, rather than the mitotic, period (Bergeron, Warmsley \& Pasternak, 1969, 1970; Warmsley \& Pasternak, 1970).

\section{Rat tissues}

Use of labelled choline as precursor of rat phospholipids. Several authors (e.g. Nagley \& Hallinan, 1968; Plagemann, 1968) have advocated the use of choline as a specific precursor of phospholipids. At the same time, caution in the use of a methyllabelled compound is necessary, since methylation of various compounds, including phospholipid acceptors such as phosphatidylethanolamine, may occur (Blumenstein, 1968; Spitzer et al. 1969) in addition to incorporation through the normal

Table $1 .{ }^{3} \mathrm{H} /{ }^{14} \mathrm{C}$ ratio of phospholipids in rats injected with $\left[\mathrm{Me}-{ }^{3} \mathrm{H}\right]$ choline and $\left[1,2-{ }^{14} \mathrm{C}_{2}\right]$ choline

Healthy rats $(100-140 \mathrm{~g})$ were injected with a solution containing $\left[M e^{-}{ }^{3} \mathrm{H}\right]$ choline $(15 \mu \mathrm{Ci} / 100 \mathrm{~g}$ body wt.) and $\left[1,2-{ }^{14} \mathrm{C}_{2}\right]$ choline $(1.5 \mu \mathrm{Ci} / 100 \mathrm{~g}$ body wt.) and killed in pairs at various times thereafter. Tissues were extracted by the method of Folch et al. (1957) as described in the Experimental section and the radioactivity of the total phospholipid fraction was measured. The ratios are means, relative to that of the injected solution taken as 1.00 .

\begin{tabular}{ccccccc} 
Time after injection & $\ldots$ & \multicolumn{5}{c}{${ }^{3} \mathrm{H} /{ }^{14} \mathrm{C}$ ratio } \\
\cline { 3 - 7 } $\begin{array}{c}\text { Tissue } \\
\text { Duodenum }\end{array}$ & & 0.98 & 1.07 & 1.15 & 1.15 & 1.05 \\
Ileum & & 0.98 & 1.09 & 1.11 & 1.13 & 1.05 \\
Colon & & 1.04 & 1.03 & 1.07 & 1.11 & 1.05 \\
Liver & & 1.11 & 1.17 & 1.34 & 1.37 & 1.25 \\
Kidney & & 1.05 & 1.05 & 1.08 & 1.15 & 1.11
\end{tabular}


biosynthetic sequence. This proved to be insignificant for the tissues studied here, with the possible exception of liver (Table 1) in which the ${ }^{3} \mathrm{H} /{ }^{14} \mathrm{C}$ ratio after injection of $\left[\mathrm{Me}^{3} \mathrm{H}\right]$ choline and $[1,2$ ${ }^{14} \mathrm{C}_{2}$ ]choline reaches $1.4: 1$; even this is still considerably lower than the values cited by Blumenstein (1968) and by Spitzer et al. (1969). Moreover, the
${ }^{3} \mathrm{H} /{ }^{14} \mathrm{C}$ ratio remains constant throughout turnover (Table 1), in marked contrast with the situation reported for mouse liver (Groth, Bain \& Pfeiffer, 1958) and is essentially the same in the phosphatidylcholine, sphingomyelin and lysophosphatidylcholine fractions of liver.

It is noteworthy that the amount of radioactivity
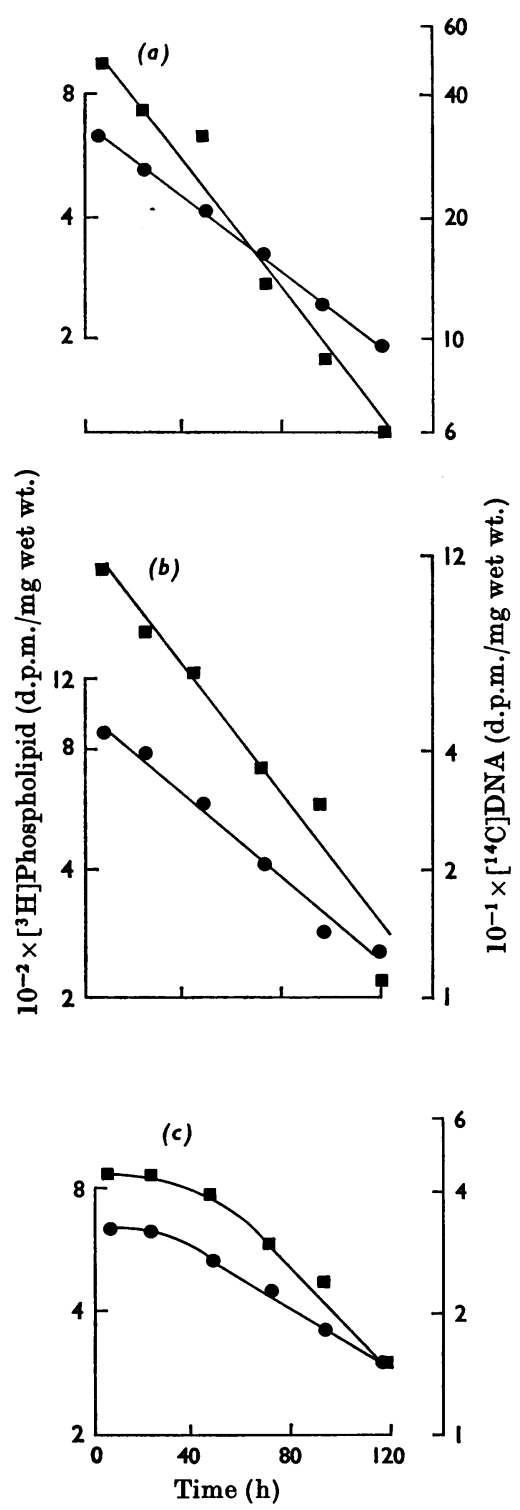

Fig. 2. Turnover of choline-labelled phospholipid and thymidine-labelled DNA in healthy rats. Rats (100g) were injected with $23 \mu \mathrm{Ci}$ of $\left[\mathrm{Me}^{-3} \mathrm{H}\right]$ choline and $2.3 \mu \mathrm{Ci}$ of $\left[{ }^{14} \mathrm{C}\right]$ thymidine and killed in pairs at various times thereafter. Tissues were extracted by the trichloroacetic acid method and the radioactivity of incorporated label was assayed as described in the Experimental section. The mean values are plotted. $(a)$ Duodenum; $(b)$ ileum; (c) colon; $(d)$ liver; $(e)$ kidney. $\bullet,{ }^{3} \mathrm{H}$-labelled phospholipid; $\mathbf{a},{ }^{14} \mathrm{C}$-labelled DNA. 
that is water-soluble decreases at the same rate as that which is lipid-soluble, the ratio (water-soluble/ total radioactivity) remaining constant at approx. $1: 3$ in all tissues examined. This may imply a rather efficient reutilization of soluble products that do not mix readily with the free choline pool. The radioactivity of blood, most of which is water-soluble $(>85 \%)$, increases slightly as might be expected from effective renal reabsorption coupled with loss from tissues.

Turnover of phospholipids in healthy rats. The behaviour of phospholipids in healthy animals essentially confirms previous results (Dawson, 1966). Thus turnover of total choline-containing phospholipids in liver is not constant, but comprises a rapid and a slower component (Fig. 2). The slower component (mean $t_{t}$ from several experiments, $100 \mathrm{~h}$ ) probably corresponds to the ${ }^{32} \mathrm{P}$-labelled mitochondrial phospholipid reported by Bailey et al. (1967) to have $t_{1}$ of 2-4 days; the long-lived phospholipid observed by Bailey et al. (1967) and by others (Gross et al. 1969), would not have been detected in the present study. The faster component (mean $t_{1}$ from several experiments $13 \mathrm{~h}$ ) may be due to exchange of choline units (Dils \& Hubscher, 1961; Treble, Frumkin, Balint \& Beeler, 1970) similar to the exchange of fatty acids noted by Pascaud (1964) and by Taylor, Bailey \& Bartley (1967), though Dawson (1957), Collins (1963) and Gurr, Prottey \& Hawthorne (1965) have found a similarly fast component based on [ $\left.{ }^{32} \mathrm{P}\right]$ phosphate incorporation, and Stein \& Stein (1969) have reported the absence of exchange reactions in liver in vivo. In any case, choline exchange is unlikely to account for turnover of the slower component, since the $\left[{ }^{3} \mathrm{H}\right]$ choline $/\left[{ }^{33} \mathrm{P}\right]$ phosphate ratio of total phospholipids, after an initial fall (perhaps due to rapid phosphatidic acid turnover) in all tissues except blood, remains constant thereafter (Fig. 3).

Turnover in intestinal tissues and kidney appears to be fairly constant (Fig. 2), the rate being approximately the same as that of the slower component of liver. Clearly the turnover of choline-containing phospholipid is not related to the rate of cell division within a particular tissue. Indeed in duodenum, ileum and colon, in which turnover of incorporated thymidine reflects the rate of cell renewal (Cleaver, 1967), the turnover of phospholipid is actually slower than that of thymidine (Fig. 2 and Table 2) (cf. Gross et al. 1969). This again implies that choline is partially reutilized within the tissue or that the bulk of the radioactivity is incorporated by cells that do not divide. The rates of DNA turnover observed in the present experiment agree with those quoted by Cleaver (1967).

Turnover of phospholipids in starved and vitamin $A$-deficient rats. Although the intestine is known to be a site sensitive to vitamin A (Moore, 1957), the uptake and turnover of choline was found to vary relatively little between 'control' and vitamin Adeficient animals (Table 2). Turnover in each case probably represents degradation and resynthesis of the whole phospholipid molecule, since the $\left[{ }^{3} \mathrm{H}\right]$ choline $/\left[{ }^{33} \mathrm{P}\right]$ phosphate ratio is constant from about $40 \mathrm{~h}$ onwards in all tissues (Fig. 3). Since 'control' animals were fed with the same amount as deficient litter mates, which soon lost appetite (Pasternak \& Thomas, 1969), they were in fact starving animals and were losing weight rapidly (Pasternak \& Thomas, 1969). It may not be surprising, therefore, that phospholipid turnover varies more between 'healthy' and 'control' than

Table 2. Turnover of choline-labelled phospholipid and thymidine-labelled DNA in intestinal tissues of healthy, starved and vitamin A-deficient rats

Rats, reared as described in the Experimental section, were injected with a solution containing [ $\left.M e-{ }^{3} \mathrm{H}\right]-$ or $\left[M e^{-14} \mathrm{C}\right]$-choline and $\left[{ }^{14} \mathrm{C}\right]-$ or $\left[{ }^{3} \mathrm{H}\right]$-thymidine, and groups of two or three were killed $1,4,24,48,72,96$ and $120 \mathrm{~h}$ later. Tissues were extracted by the trichloroacetic acid method. The results were plotted on semi-log paper and half-lives $\left(t_{1}\right)$ read off. The values are means \pm S.E.M., with the numbers of experiments given in parentheses.

\begin{tabular}{|c|c|c|c|}
\hline & \multicolumn{3}{|c|}{$t_{1}(h)$} \\
\hline & \multirow[t]{2}{*}{ Healthy rats } & \multicolumn{2}{|c|}{ Starved rats } \\
\hline & & Control & $\begin{array}{c}\text { Vitamin A- } \\
\text { deficient }\end{array}$ \\
\hline $\begin{array}{l}\text { Phospholipid } \\
\text { Duodenum } \\
\text { Ileum } \\
\text { Colon }\end{array}$ & $\begin{array}{l}67 \pm 3(3) \\
61 \pm 5(3) \\
83 \pm 12(3)\end{array}$ & $\begin{array}{r}112 \pm 15(3) \\
95 \pm 15(3) \\
203 \pm 27(3)\end{array}$ & $\begin{array}{r}112 \pm 20(3) \\
75 \pm 3(3) \\
150 \pm 38(3)\end{array}$ \\
\hline $\begin{array}{l}\text { DNA } \\
\text { Duodenum } \\
\text { Ileum } \\
\text { Colon }\end{array}$ & $\begin{array}{l}37(1) \\
33(1) \\
66(1)\end{array}$ & $\begin{array}{l}40 \pm 4(4) \\
45 \pm 6(4) \\
90 \pm 27(4)\end{array}$ & $\begin{array}{l}41 \pm 7(4) \\
41 \pm 7(4) \\
74 \pm 13(4)\end{array}$ \\
\hline
\end{tabular}




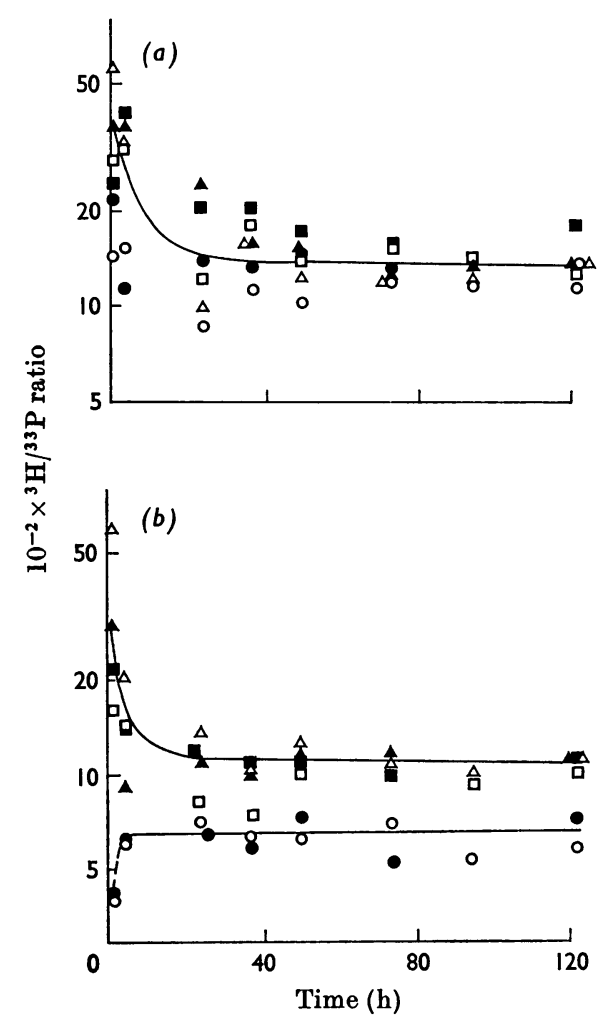

Fig. 3. ${ }^{3} \mathrm{H} /{ }^{33} \mathrm{P}$ ratio of phospholipids in rats injected with $\left[M e-{ }^{3} \mathrm{H}\right]$ choline and $\left[{ }^{33} \mathrm{P}\right]$ phosphate. Pairs of control and vitamin A-deficient rats were injected with $\left[M e-{ }^{3} \mathrm{H}\right]$ choline $(5 \mu \mathrm{Ci} / 100 \mathrm{~g}$ body wt. $)$ and $\left[{ }^{33} \mathrm{P}\right]$ phosphate $(0.5 \mu \mathrm{Ci} / 100 \mathrm{~g}$ body wt. $)$ and killed at various times thereafter, and tissues were extracted by the method of Folch et al. (1957) as described in the Experimental section. (a) Duodenum, O, control and $\bullet$, deficient rats; ileum, $\Delta$, control and $\Delta$, deficient rats; colon, $\square$, control and $\square$, deficient rats. (b) Blood, $O$, control and $\bullet$, deficient rats; kidney, $\Delta$, control and $\Delta$, deficient rats; liver, $\square$, control and $\mathbf{a}$, deficient rats.

between 'control' and deficient rats (Table 2). Indeed, what variation does exist between 'control' and deficient animals may be due to the somewhat greater weight loss of the 'control' rats. The same is probably true of DNA turnover also (Table 2), which like that of ${ }^{35} \mathrm{~S}$-labelled mucopolysaccharides (Pasternak \& Thomas, 1969; Thomas \& Pasternak, $1969)$ is marginally faster in deficient animals.

It is clear that starvation, whether caused by vitamin A deficiency or otherwise, leads to a decrease in the turnover of phospholipid. A similar result was reported (Artom et al. 1938; Bailey et al. 1967) for animals made deficient in essential fatty acids.
Nature of choline-labelled phospholipids during turnover. As expected (e.g. Balint et al. 1967; Arvidson, 1968; Nagley \& Hallinan, 1968; Stein \& Stein, 1969), most of the radioactivity incorporated from labelled choline by liver is present in the phosphatidylcholine fraction (Table 3). The same is true of kidney, blood and intestinal tissues and is independent of the nutritional status of the animals. During turnover, the pattern changes in just the way observed with neoplastic mast cells (Pasternak \& Bergeron, 1970); as might be expected (Table 2), the percentage of label in phosphatidylcholine decreases slightly more in healthy than in starved (vitamin A-deficient) animals. In other words, the relatively greater metabolic instability of certain lecithins (e.g. Collins, 1963; Balint et al. 1967; Arvidson, 1968; Rytter et al. 1968; Kanoh, 1969; Spitzer et al. 1969; Van Golde et al. 1969) compared with sphingomyelin or lysophosphatidylcholine appears to be almost as widespread a phenomenon as phospholipid turnover itself. In blood the pattern remains unchanged (Table 3); since the relatively low amount of incorporated label does not turn over (Fig. 2), this is the expected result and confirms previous reports (Dawson, 1966) of the metabolic stability, apart from exchange of intact molecules with serum phospholipids (Shohet \& Nathan, 1970), of erythrocyte phospholipid. Extracts of tissues that have been kept for some time undergo chemical degradation. In that case also, the percentage of radioactivity found in the phosphatidylcholine area on t.l.c. decreases at the expense of that in the sphingomyelin area. But in contrast with enzymic turnover, such changes are accompanied by the appearance of radioactivity in the lysophosphatidylcholine area and at the origin.

The precise physiological significance of phospholipid turnover remains obscure. What appears to emerge from these studies of neoplastic mast cells (Pasternak \& Bergeron, 1970), lymphocytes and rat tissues in vivo is that healthy, growing cells have high, rather than low, rates of turnover and the same may be true of membrane proteins also (see, e.g., Orrenius, Ericsson \& Ernster, 1965). Perhaps the degradation and resynthesis of the constituents of membranes is a prerequisite not only of cells actually growing (such as intestinal tissues and exponentially growing neoplastic mast cells), but also of cells (such as liver and kidney, unstimulated lymphocytes and neoplastic mast cells in lag or stationary phase) having the potentiality to grow and divide. This may be related to the sensitivity of cellular membranes to hormonal (Peters, 1956; Tata, 1967, 1970) and other types (Kuriyama, Omura, Siekevitz \& Palade, 1969) of metabolic control. A system that is essentially dynamic is clearly more susceptible to functional variation than one that is static. 
Table 3. Distribution of label in phospholipids of healthy and vitamin A-deficient rats injected with $\left[M e-{ }^{3} \mathrm{H}\right]$ choline

Healthy and vitamin A-deficient rats were injected with $\left[M e^{-3} \mathrm{H}\right]$ choline and killed in groups of three at 4 and 100 or $116 \mathrm{~h}$. Tissues were extracted by the method of Folch et al. (1957) and analysed by t.1.c. as described in the Experimental section. Two experiments were carried out with healthy rats and the results of these are pooled. Values are means \pm S.E.M. with the numbers of samples given in parentheses.

Phospholipid radioactivity (as \% of total recovered after t.l.c.)

Tissue Area on plate

Blood Lysophosphatidylcholine Sphingomyelin Phosphatidylcholine

Duodenum Lysophosphatidylcholine Sphingomyelin Phosphatidylcholine

Ileum Lysophosphatidylcholine Sphingomyelin Phosphatidylcholine

Colon

Liver

Kidney
Lysophosphatidylcholine Sphingomyelin Phosphatidylcholine

Lysophosphatidylcholine Sphingomyelin Phosphatidylcholine

Lysophosphatidylcholine Sphingomyelin Phosphatidylcholine

\begin{tabular}{|c|c|c|c|}
\hline \multicolumn{2}{|c|}{$4 h$} & \multirow{2}{*}{$\begin{array}{l}100 \text { or } 116 \mathrm{~h} \\
\text { Healthy rats }\end{array}$} & \multirow{2}{*}{$\begin{array}{c}100 \mathrm{~h} \\
\text { Vitamin A- } \\
\text { deficient rats }\end{array}$} \\
\hline Healthy rats & $\begin{array}{c}\text { Vitamin A- } \\
\text { deficient rats }\end{array}$ & & \\
\hline $\begin{array}{l}16.1 \pm 1.2(6) \\
11.7 \pm 1.5(6) \\
63.3 \pm 4.1(6)\end{array}$ & $\begin{array}{l}17.8 \pm 1.5(3) \\
14.6 \pm 1.8(3) \\
64.7 \pm 4.0(3)\end{array}$ & $\begin{array}{r}9.5 \pm 2.2(5) \\
15.3 \pm 1.8(5) \\
66.6 \pm 2.7(6)\end{array}$ & $\begin{array}{r}8.8 \pm 1.3(3) \\
14.9 \pm 1.3(3) \\
72.3 \pm 1.6(3)\end{array}$ \\
\hline $\begin{array}{r}4.5 \pm 0.9(6) \\
6.2 \pm 0.5(6) \\
85.0 \pm 3.1(6)\end{array}$ & $\begin{array}{r}2.2 \pm 0.2(3) \\
5.6 \pm 0.4(3) \\
91.6 \pm 0.5(3)\end{array}$ & $\begin{array}{r}1.3 \pm 0.2(5) \\
22.0 \pm 2.3(5) \\
72.1 \pm 3.1(5)\end{array}$ & $\begin{aligned} 1.5 & (2) \\
18.1 & (2) \\
78.0 & (2)\end{aligned}$ \\
\hline $\begin{array}{r}2.4 \pm 0.6(6) \\
7.3 \pm 1.0(6) \\
89.6 \pm 1.6(6)\end{array}$ & $\begin{array}{r}2.9 \pm 0.6(3) \\
7.4 \pm 0.8(3) \\
88.5 \pm 0.7(3)\end{array}$ & $\begin{array}{r}2.3 \pm 0.7(6) \\
24.6 \pm 0.4(6) \\
69.7 \pm 2.3(6)\end{array}$ & $\begin{array}{r}2.3 \pm 0.2(3) \\
18.9 \pm 0.3(3) \\
77.7 \pm 0.9(3)\end{array}$ \\
\hline $\begin{array}{r}2.8 \pm 0.3(6) \\
5.7 \pm 0.4(6) \\
90.6 \pm 0.6(6)\end{array}$ & $\begin{array}{r}2.3 \pm 0.5(3) \\
6.8 \pm 1.2(3) \\
90.0 \pm 0.6(3)\end{array}$ & $\begin{array}{r}1.7 \pm 0.2(6) \\
25.9 \pm 2.4(6) \\
68.4 \pm 3.4(6)\end{array}$ & $\begin{array}{r}1.7 \pm 0.2(3) \\
22.0 \pm 0.7(3) \\
75.2 \pm 0.7(3)\end{array}$ \\
\hline $\begin{array}{r}1.6 \pm 0.1(6) \\
6.4 \pm 1.1(6) \\
90.8 \pm 1.3(6)\end{array}$ & $\begin{array}{r}1.5 \pm 0.1(3) \\
6.3 \pm 0.2(3) \\
91.0 \pm 0.3(3)\end{array}$ & $\begin{array}{r}3.1 \pm 1.0(6) \\
14.1 \pm 1.6(6) \\
72.2 \pm 3.2(6)\end{array}$ & $\begin{array}{r}1.6 \pm 0.4(3) \\
14.3 \pm 3.1(3) \\
81.4 \pm 3.5(3)\end{array}$ \\
\hline $\begin{array}{r}2.0 \pm 0.3(4) \\
6.2 \pm 0.5(4) \\
88.9 \pm 1.0(6)\end{array}$ & $\begin{array}{r}3.7 \pm 0.5(3) \\
7.5 \pm 0.8(3) \\
86.2 \pm 0.8(3)\end{array}$ & $\begin{array}{r}0.8 \pm 0.1(6) \\
33.6 \pm 1.0(6) \\
60.6 \pm 0.8(6)\end{array}$ & $\begin{array}{r}0.8 \pm 0.4(3) \\
35.6 \pm 0.7(3) \\
60.8 \pm 1.1(3)\end{array}$ \\
\hline
\end{tabular}

We are indebted to Miss Pamela Allan, Mrs Marilyn Jeeves and Mr Ted Kohler for their assistance and collaboration at various stages of this work.

\section{REFERENCES}

Artom, C., Sarzana, G. \& Segré, E. (1938). Archs int. Physiol. 47, 245.

Arvidson, G. A. E. (1968). Eur. J. Biochem. 5, 415.

Bailey, E., Taylor, C. B. \& Bartley, W. (1967). Biochem.J. $104,1026$.

Baker, F. J., Silverton, R. E. \& Luckcock, E. D. (1957). An Introduction to Medical Laboratory Technology, 2nd ed., p. 281. London: Butterworth and Co. Ltd.

Balint, J. A., Beeler, D. A., Treble, D. H. \& Spitzer, H.L. (1967). J. Lipid Res. 8, 486.

Bergeron, J. J. M., Warmsley, A. M. H. \& Pasternak, C. A. (1969). FEBS Lett. 4, 161.

Bergeron, J. J. M., Warmsley, A. M. H. \& Pasternak, C. A. (1970). Biochem. J. 119, 489.

Blumenstein, J. (1968). Can.J. Physiol. Pharmac. 46, 48. Cleaver, J. E. (1967). Thymidine Metabolism and Cell Kinetics, p. 184. Amsterdam : North-Holland Publishing Co.

Collins, F. D. (1960). Nature, Lond., 186, 366.

Collins, F. D. (1963). Biochem. J. 88, 319.

Daniels, M. J. (1969). Biochem. J.115, 697.

Dawson, R. M. C. (1957). Biol. Rev. 32, 188.

Dawson, R. M. C. (1966). In Essays in Biochemistry, vol. 2, p. 69. Ed. by Campbell, P. N. \& Greville, G. D. London : Academic Press.
Dils, R. R. \& Hubscher, G. (1961). Biochim. biophys. Acta, 46, 505.

Dingle, J. T. \& Lucy, J. A. (1965). Biol. Rev. 40, 422.

Elsbach, P. (1967). J. Lipid Res. 8, 359.

Fisher, D. (1968). Fedn Proc. Fedn Am. Socs exp. Biol. 27, 644 .

Fisher, D. B. \& Mueller, G. C. (1969). Biochim. biophys. Acta, 176, 316.

Folch, J., Lees, M. \& Sloane-Stanley, G. H. (1957). J. biol. Chem. 226, 497.

Forsdyke, D. R. (1967). Biochem. J. 105, 679.

Forsdyke, D. R. (1968). Biochem. J. 108, 297.

Gross, N. J., Getz, G. S. \& Rabinowitz, M. (1969). J. biol. Chem. 244, 1552.

Groth, D. P., Bain, J. A. \& Pfeiffer, C. C. (1958). J. Pharmac. exp. Ther. 124, 290.

Gurr, M. I., Prottey, C. \& Hawthorne, J. N. (1965). Biochim. biophys. Acta, 106, 357.

Harris, P. N., Robinson, D. S. \& Getz, G. S. (1960). Nature, Lond., 188, 742.

Isozaki, M., Yamamoto, A., Amako, T., Sakai, Y. \& Okita, H. (1962). Med.J. Osaka Univ. 12, 285.

Kanoh, H.(1969). Biochim. biophys. Acta, 176, 756.

Kay, J. E. (1968). Nature, Lond., 219, 172.

Kuriyama, Y., Omura, T., Siekevitz, P. \& Palade, G. E. (1969). J. biol. Chem. 244, 2017.

Levin, E., Johnson, R. M. \& Albert, S. (1958). Archs Biochem. Biophys. 73, 247.

Lubochinsky, B. \& Burger, M. M. (1969). Abstr. FEBS 6th Meet., Madrid, p. 345. 
Moore, T. (1957). Vitamin A, pp. 296, 304. Amsterdam: Elsevier Publishing Co.

Mueller, G. C. \& Le Mahieu, M. (1966). Biochim. biophys. Acta, 114, 100.

Nagley, P. \& Hallinan, T. (1968). Biochim. biophys. Acta, $163,218$.

Nowell, P. C. (1960). Cancer Res. 20, 462.

Orrenius, S., Ericsson, J. L. E. \& Ernster, L. (1965). J. Cell Biol. 25, 627.

Pascaud, M. (1964). Biochim. biophys. Acta, 84, 528.

Pasternak, C. A. (1969). Abstr. FE BS 6th Meet., Madrid, p. 209.

Pasternak, C. A. \& Bergeron, J. J. M. (1970). Biochem. J. $119,473$.

Pasternak, C. A. \& Thomas, D. B. (1969). Am. J. clin. Nutr. 22, 983.

Peters, R. A. (1956). Nature, Lond., 177, 426.

Plagemann, P. G. W. (1968). Archs Biochem. Biophys. 128, 70.

Roberts, R. B., Abelson, P. H., Cowie, D. B., Bolton, E. T. \& Britten, R. J. (1957). Studies of Biosynthesis in Escherichia coli, p. 13. Washington, D.C.: Carnegie Institution of Washington.

Rytter, D., Miller, J. E. \& Cornatzer, W. E. (1968). Biochim. biophys. Acta, 152, 418.
Shohet, S. B. \& Nathan, D. G. (1970). Biochim. biophys. Acta, 202, 202.

Smith, M. E. (1969). Biochim. biophys. Acta, 164, 285.

Spitzer, H. I., Norman, J. R. \& Morrison, K. (1969). Biochim. biophys. Acta, 176, 584.

Stein, D. \& Stein, Y. (1969). J. Cell Biol. 40, 461.

Stoeckenius, W. \& Engelman, D. M. (1969). J. Cell Biol. $42,613$.

Tata, J. R. (1967). Biochem. J. 104, 1.

Tata, J. R. (1970). Biochem. J. 116, 617.

Taylor, C. B., Bailey, E. \& Bartley, W. (1967). Biochem.J. $105,605$.

Thomas, D. B. \& Pasternak, C. A. (1969). Biochem. J. $111,407$.

Treble, D. H., Frumkin, S., Balint, J. A. \& Beeler, D. A. (1970). Biochim. biophys. Acta, 202, 163.

Van Deenen, L. L. M. (1966). In Progress in the Chemistry of Fats and other Lipids, vol. 8, p. 1. Ed. by Holman, R.T. Oxford: Pergamon Press Ltd.

Van Golde, L. M. G., Scherphof, G. L. \& Van Deenen, L. L. M. (1969). Biochim. biophys. Acta, 176, 635.

Warmsley, A. M. H. \& Pasternak, C. A. (1970). Biochem.J. $119,493$.

Warren, L. (1969). Curr. Topics devl Biol. 4, 197. 